\title{
The Innovative Role of the Islamic World to Counter the Phenomenon of Western "Islamophobia" during the Post-Corona Era
}

\author{
Muhammad Umar Riaz Abbasi, Lecturer, PhD Scholar National University of Modern Languages Islamabad \\ Pakistan, drumarabbasi101@gmail.com \\ Dr Hafiz Haris Saleem, Assistant Professor Kohsar University Murree \\ Tariq Ejaz, Assistant Professor Air University Islamabad \\ Dr Sana Ullah, Assistant Professor Bahria University Islamabad \\ Dr Hafiz Muhammad Mushtaq, Assistant Professor Government College Eimen Abad Gujranwala \\ Dr Mohsin Abbasi, Lecturer NUML Islamabad
}

\begin{abstract}
This article focuses on the examination of prejudice against Islam and Muslim community immigrants in the Western world. The literature contained explains the anti-Muslim bigotry at the state level by multiple factors. Additionally, this article conducts a historical, descriptive, and critical analysis of Islamophobic origin, frames, enabling factors, dissemination strategies, along with its impact on the Muslim community residing in the western world. Furthermore, reasons behind the Islamophobic culture has also been mentioned and explained. Moreover, this study vastly explains the impact of pandemic- COVID 19 on spreading of Islam and Muslim hatred among the west people. Emphases have also been laid upon the strategies which should be adopted to counter attack the concept of Muslims as "Others" in the western world. The innovative role played by the Muslim leaders and Islamic world is also discussed which can contribute to fight the prejudiced mindset about Islam and its followers. Specifically, findings have suggested that in the perspective of historical importance of Islamophobia, the main cause behind it is that western world is unaware of the basic teachings and purpose of Islam. They have very limited or maybe no knowledge about the Muslims. This factor is contributing majorly in raising the hatred among west and Muslim. Due to this, Muslims are facing disastrous conditions there in the west, regarding their living standards, employment, education, or even their social interactions are highly compromised. Muslims have been labeled there as "Inferior", and "Terrorists" based just upon their physical attire i.e., men with beards and women with hijab. All these biased concepts can be eradicated if the Muslim world unites and take bold steps to spread the real message of Islam as a religion of peace, harmony, justice, and equality. Several platforms can be utilized for this purpose including social media, refining literature and educating people, through speeches at universal platforms as UN assembly.
\end{abstract}

Keywords: Islamophobia, Pandemic, Muslim world, West, Innovative role.

Received: 07.12.2020 Accepted: 15.01.2021 Published: 03.02.2021

\section{INTRODUCTION}

Western counties have experienced a constant and large inflow of immigrants in the $20^{\text {th }}$ century. Immigrants' number increased rapidly in the western world with the arrival of foreign laborers being recruited, the prior colonies, refugees, family reunions, and asylum seekers. Hence by the start of $21^{\text {st }}$ century, several western states have become multiethnic- though just a half century ago they were all homogenous. Furthermore, even though the immigrants belonged to different states and were religiously diverse, most among them were Muslims, sharing the background of Islam. Consequently, Muslims became the second most populous religious community in the West, making up around five percent of the total population. However, the host countries have never welcomed the immigrants with the positive attitude. Factually, since the arrival of the immigrants in West, particularly Muslims have been fronting crucial heights of discrimination, biasness, and prejudice, to the extents that even endangers the wellness of a society. The $9 / 11$ extremist attacks, which occurred between 2001 and 2013 is an example, in which 50\% of the British mosques were targeted in different ways. Furthermore, the rise of western far-right, where the sentiments against Muslims and immigrants find portrayal is another expression of prejudice against Muslims. Islamophobia has its roots dwelled in the history as well. Because of orientalist generalizations and dichotomies, identity of Muslims is 
associated with the undesirable stereotypes since long in Western world. The historical identity of Muslims as "Other" has been influenced by Ottoman Empires' legacy. Such facts explain the centralized prejudiced attitude of western world against the Muslims. However, these extraordinary levels of discrimination, exclusion, and prejudice are the matter of concern for democracy, which is something that holds tolerance, religious freedom, and equality among the fundamental values. Also, weakened social peace and harmony and social discrimination are paced up due to these negative expressions and views.

This study thus focuses on the emerging factors of Islamophobia in the Western World. Historical perspective of Islamophobia, highlighting the role of Orientalism and racialization in enabling the Islamophobia, is also discussed. Contribution of Biases' internalization, Xenophobia, ignorance of Muslims and their religion Islam, and network of Islamophobia being the contemporary factors in the onset of Muslim hatred is explained. Routes of dissemination of Islamophobia, i.e. via news channels, TV shows, course books and web-links, campaigns and different political forums are discoursed as well. Afterwards, impact of the current pandemic situation on Islamophobic believes of western societies is highlighted. Furthermore, the innovative role that should be played by the Muslim world in order to counter attack this biased concept against Muslims, sharia, and Islam is under discussion as well. Youth of the west should be made aware of the true essence of the real Islam through educational and electronic media platform. It's essential to make the world realize that Islam is not the religion of fear and terror, but peace, unity, and harmony. Counternarrative of Islamophobia needs to be given boldly by the leaders of Islamic state through universally recognized platforms including UN Assembly. Every bill related to the promotion of Islamophobia needs to be nullified and confiscated globally, so that Muslims can enjoy their rights and carry out their religious activities freely wherever they want. Social websites, TV shows and related materials need to be banned worldwide in order to stop the wave of negativity about Islam and Muslims.

\section{Area and objective of the research}

Objective of the current study is to portray the religion of Muslims, Islam as a religion of peace, harmony, justice, and equality. Islam believes in social justice and equality. According to article 63 of constitution of Madinah, Islam is a state of Madinah which provides equal citizenship to both the believers and nonbelievers. Social rights of every being are equal, even minorities are given the equal rights. Every person, regardless of the religion, is free to follow their religious practices. Moreover, killing of any minority in Islam, without a proper reason, is unjustified and forbidden according to the teachings of Allah SWT-Quran and Hazrat Muhammad SAWW-Sunnah and Ahadith. Additionally, peace and prosperity are the key teachings of Islam. Even, finding from the sayings of Hazrat Muhammad SAWW states, "The best among people is the one, who is best for others". Islam addresses humanity for the rights and security of humanity. Moreover, portraying the image of Muslims and Islam in the western world is the objective of the current research, to highlight the sufferings of Muslims, how they have been tortured on the name of religion and its causative factors are the goals to conduct this study. Also, reason of dissemination of Islamophobia in the West is the key aim of this study, i.e. the west societies do not understand Islam as per its true spirit. ISIS and such organizations are not the true representatives of Islam. Most of the Muslim community abides by the teachings of Islam and Sunnah. The role that should be played by the Muslim leaders to counter attack Islamophobia is also the key goal of this study.

\section{RESEARCH METHODOLOGY}

Historical, Critical and descriptive analysis is the method employed for the research conducted.

\section{What is Islamophobia?}

English dictionary of oxford defined Islamophobia to be the prejudice or dislike against the Muslims or Islam, prominently as the governmental force and in the recent times indicates anti-Muslim actions and attitudes. The term of Islamophobia was used for the first time in 1923 and became a widely practiced term in the November, 1997 after the publication of a report with a title Islamophobia: A challenge for us all. This report was originated and published by the commission which was supported by Great Britain's Runnymede Trust. In this report Islamophobia was defined as the global-view or outlook which involves speculative terror and hatred of Muslims, which brings about practical discrimination and exclusion as a result. Runnymede, in 1997, redefined Islamophobia in a shorter statement as Anti-Muslim racism. A detailed description was also released based on the racism's definition given by United Nations (UN) as: "Islamophobia is the restriction, 
discrimination, and exclusion in the direction of, or priority against the Muslims (real or perceived) with the intended output of weakening or nullifying the exercise, recognition, or enjoyment on equal terms of fundamental rights and freedom of human in economic, cultural, political, social, or other public life related fields". Islamophobia as a fear generating industry or anti-Islamic bigotry is what viewed by Islamic Networks Group (ING).

\section{Frames of Islamophobia}

The report generated by Runnymede also enlisted various ideas and frames associated with the Muslims and Islam as follows:

1. Islam is perceived as the static, monolithic religion with no response to change.

2. It is viewed as supplementary and isolated. It lacks common cultural values with any other religious conviction, unaffected, and uninfluenced by them.

3. It is considered to be sexist, irrational, barbaric, and primitive and substandard as compared to the West.

4. Terrorism supporting, involved in the clash of different civilizations, violent, threatening, and aggressive are the tags associated to Islam.

5. Islam is observed as a governmental ideology, exploited for military and political benefits.

6. Muslims made criticisms about the West are rejected.

7. Aggression for Islam is exploited for the justification of Muslims' practical discrimination and segregation of Muslim community from the general public.

8. Anti-Islamic aggression is rendered as ordinary and natural.

\section{Factors enabling Islamophobia}

There are several factors contributing towards the enabling of Islamophobia such as, historical and contemporary factors. Historical factors include orientalism and racialization. Whereas, contemporary factors includes Biases' internalization, Xenophobia, ignorance of Muslims and their religion Islam, and network of Islamophobia.

\section{Historical factors}

\section{Orientalism}

Definition: "Characteristic artifacts, traits, or styles of Asian cultures and people" and "stereotypic Asian representation considered as symbolizing the attitudes of colonialists".

History: In $18^{\text {th }}$ and $19^{\text {th }}$ century, this term was employed which referred to the study conducted by the scholars of western states of societies and subjects of Asia, Middle East, and North Africa categorized by captivation with the exotic lifestyle and culture considered by those scholars. Europeans intentionally or unintentionally has dissected the world into two broad categories: the uncivilized orient or East, and the civilized occident or the west. Europeans demarcated themselves to be the grander race and recognized it their responsibility to bring about civilization in uncivilized societies, the prominent validation for colonialism. In 1978, from Columbia University, Prof. Edward Said stated in his leading book named "Orientalism" that orientalist scholars which were basically Anglo-Americans portrayed the people of "East" as the exotic "Others". Also, they referred eastern people to be profoundly dissimilar from and substandard as compared to the Western civilization, exhibiting them as fundamentally irrational, despotic, primitive, fanatic, and violent. Colonial enterprise of Europe was justified by these representations by making these cultures and Muslim communities to be the threat for western people and civilization.

\section{Orientalism leading to Islamophobia}

European poets and writers have romanticized the Eastern people and idealized their point of view about the simplistic nature of orients which have made them substandard as compared to the Europeans. Furthermore, they have demonstrated the eastern inhabitants as depraved, different, irrational, and childlike, rendering Europeans as virtuous, normal, rational, and mature. Whatever the Europeans observed in the period of their visits interpreted it as the representation of the norms of all eastern people. This helped them to formulate their very own narrative regarding orient people, especially Muslims. Several stereotypes among them exhibited the Muslims to be sexist and sexually promiscuous, violent, irrational, and primitive. Post WW-I Eastern peoples' attitudes shifted towards the United States and political policies for the country in that 
region were founded through the Eastern scholarship. Amid the WW-II and defeat of several colonies of Europe, most of the bigotries against the Orients, especially Muslims resurfaced and continued in the Western societies as Islamophobia. Today, the Western people consider Muslims to be responsible for extremism and terrorism.

\section{Racialization}

Background and process: Related group of individuals with common heredity and descent is something termed as "Race". Racialization is the process which demonstrates the categories of different races involving the individuals with definite common ancestral and physical similarities. Racial groups are assigned with certain characteristics, and racialization then formulates a hierarchy which honors Christianity and the "whiteness" and rationalizes the oppression of other groups by claiming them to be less privileged. Racialization is basically employed by the powerful groups, who use different policies for the reinforcement of surviving hierarchies of several races.

\section{Models of allocating assorted groups into Racialized groups}

Racialization is the phenomenon which categorizes the various groups in racial hierarchies in such a way that are new to those groups for their own identification. For example, "Africans" (also known as Blacks), comprising of distinct tribes of various Africans, based on their cultures, similar looks, and language were put into one racial category by Europeans. Native Americans with diversified languages, tribes and cultures were assigned the category of American "Indians". "Hinduism" is the category with richly diversified cultural and religious traditions, formulated by British, and followers of this category are known as "Hindus". Today, the Muslims, regardless of their foundations in 50-majority Islamic territories accompanying varied languages, races, cultures, and ethnicities have been marked up as single monolithic clan. This category comprises any individual who "resembles Muslims", whether be it complexion of people, males with turbans and having beards, females wearing hijabs, no matter if they are converted Muslims. This category may also consists of non-Muslims enrooted in countries or regions of Muslims as majority, e.g. Sikhs, Hindus, Christian Arabs and all those who may be confused commonly with the Muslims. In fact, Balbir Singh Lodhi, a Sikh, was a first person who was killed amid 9/11 attack. Since then, Sikh community has been victimized as the target of murders and hate crimes. For instance, in the February 2019, a Sikh employee was brutally victimized through punches and being thrown hot coffee on him by an individual who upon investigation confessed that he hate the Muslims. In 2018, all party parliamentary groups (APPG) redefined Islamophobia as "Islamophobia is entrenched in a type of racism that is targeted towards the expression of perceived or real Muslimness.

\section{Contemporary factors}

\section{Biases internalization}

The term "internalize" refers to the incorporation (of cultural patterns, values etc.) within the individuals as regulatory ideologies via socialization and learning. This is also applicable on the people as "internalization" is defined as "adopting good and bad stereotypes about everyone in the group". The targeted people subconsciously or may be consciously internalizes these kind of beliefs regarding themselves. These beliefs are originated from both individual (parents, friends, etc.) and mainstream (internet and social media) sources.

\section{Implicit bias in internalization}

On contrary to consciousness based explicit bias, "Implicit bias" is the "Internalization of the beliefs of people, belonging to various groups, based upon their culture, race, customs, religion, or any other factor laying the foundation of attitudes directed towards the unconscious groups of people. Biases are change resistant irrespective of the fact that assumptions of the people are challenged. Moreover, almost every person creates implicit bias for others. It's a general point of view to think positive about the people who resonate with our personality and negative about those who have sharp differences from ours. Bias or prejudice is disseminated by conformism with the culture having dominant values which also explicit the failure of minorities in favoring their ethnicity within America. In 2012, a task force of American Psychological Association generated a report which addressed the prevention of discrimination and promotion of diversity. This report concluded that biases- inclusive of implicit biases- are universal among all the institutions and people involved. Some 
exemplary cases of biased visions regarding other groups are inclusive of Muslims categorized as nonAmerican terrorists, Blacks were classified to be dangerous, and Latinx as undocumented. Several studies have been conducted focused on establishing a relation between behavior of individuals and implicit bias. These studies have come up with the outcome that implicit bias envisages our behaviors more precisely as compared to our conscious ethics. This is the enough reason to explain that why discrimination, racial profiling, and prejudice are still universal complications in the states, regardless of decades of equal-rights legislatures.

\section{Xenophobia}

Fear of "others" and/or "foreigners" is referred to as "Xenophobia". It is most often faced by the new immigrants, justified by and based upon racism. Xenophobia is basically the expression of racialization as it focuses on the new colonizers as a component of racial discrimination with not being worthy to be the part of mainstream social culture and different from the rest of the people. They are not given the equal rights as that of the majority. The working principle of xenophobia is based on the concept of a pseudo "dominant culture". This culture is supposed to consists of the practices and standards which are characteristically dominant in a specified social, economic, and political entity comprising of various cultures. This culture is then marked as a standard unit, based on which groups of people are judged. Ones who do not belong to this standard, e.g., new immigrants, are not included in the dominant culture. This gives rise to the xenophobic approaches, as in criticizing and fearing the individuals with the different language patterns, religious norms and practices, and traditions, which are not acceptable by the dominant culture.

\section{History of American xenophobia}

In the United states, since the rise of European colonization, the Africans and Native Americans were considered and treated as "Others" or "subhuman" by the US settlers. They intended to snatch the formers' terrestrial properties and enslave the upcoming "Others". While, excluding America resident Africans and its natives, US comprise new immigrants the most and possess an extensive history of xenophobic successive waves towards targeting the different groups. In 1840s, because of the origin and catholic faith, the Irish group was among the earliest to confront the anti-immigrant attitudes. Furthermore, they were censured and hated by the major population of Protestants. In 1882, Chinese Exclusion Act (CEA) was passed under the light of hostility in the West faced by Chinese-Americans due to racial discrimination and jobs competition for economic development. This act implemented the ban of Chinese immigration to America and prohibited the already living Chinese in the US from acquiring the position of natural citizens of America. Since the end of $19^{\text {th }}$ to the beginning of $20^{\text {th }}$ century, the quotas leading to decreased immigration were introduced because of the bias and bigotry of rising colonization of people from Eastern and Southern Europe, specially Jews and Italians. Furthermore, the history of Anti-Mexican aggression is deep rooted in United States. This aggression was augmented amid the successful war of United States against Mexican-Americans in 1848. Moreover, Japanese-Americans were imprisoned on West Coast in the camps as a "safety" precaution. Also, just like Arabs, South Asians, and Muslims, Latinx groups are facing the discriminating and bigotry policies today.

\section{Ignorance of Muslims and their religion Islam}

This is yet another factor that enabled Islamophobia in the west. This is because of the fact that there are only $1-2 \%$ of Muslims in the US hence most of its people do not know about Islam and Muslims really well. In a Pew report, an interview was conducted which showed that only $38 \%$ of the people knew Muslim, $87 \%$ knew Catholics whereas, $61 \%$ of the interviewed people knew Jewish. Moreover, Public Religion Research Institute conducted a study which elaborated the interaction of Americans with different religious groups. Less than $8 \%$ Americans were found to have daily contact with Muslims. Around 29\% of them have hardly interacted with Muslims, while $62 \%$ of them declared to have rare $(26 \%)$ or certainly no (36\%) conversation with the Muslims. Furthermore, this study brought about the outcome stating that merely $16 \%$ of the entire public had a vast knowledge regarding religious dogmas and standards of Muslims while, 1/10 said that they almost know (57\%) or do not know (26\%) at all about Islam. These figures remained unchanged in 3 decades notwithstanding 9/11 incident, two phenomenal wars in the Muslim-majority states and several outreach campaigns at local and national level by mosques and different organizations. 


\section{Nominal Education about Islam In Western history}

Furthermore, American curriculum included Islamic education just a few decades ago, schools of the public sector even then provided the students with almost no or very slight Islamic education, and the education given was mostly incomplete, biased, and even inaccurate. Consequently, the youth today went deprived of the opportunity to learn and know about Islam, not even to the extent they have known about other religions such as Judaism and Christianity. This dearth of knowledge has resulted into biasness and fear leading to Islamophobia. Moreover, in spite of the publishers bringing about the textbooks with greater emphasis on portraying the accurate knowledge about the religion of Muslims and other Non-Western peoples' religion, the course instructors continue to practice unfair and prejudiced materials while teaching about terrorism, Islam, and 9/11. Core curriculum about the history of Muslims and practices of Islam may implement the Eurocentric scope to overlook the Muslims' contributions or impose them to be subordinate to the contributions of Europeans, or depict the Muslim community as opponent. Syllabus being taught about current Muslim societies mostly validates the typical interpretations that Muslims are misogynistic, modernism incompatible, and antiquated.

\section{Network of Islamophobia}

Islamophobic network is defined as "the set of organizations involved in the promotion and dissemination of views triggering Islamophobia". This definition was published in the extensive reports presented by Council on American-Islamic Relations-DC (CAIR-DC) along with the Center of American Progress (CAP). Reports from CAP published in the year 2015 and 2016 have nominated 33 organizational systems involved in the propagation of (inner core) Islamophobia, whereas 41 were those involved in the contribution and spread of the ideology of (outer core) Islamophobia. National review, the Rush Limbaugh show, Fox News, Washington times, and Savage Nations are the protruding "outer core" media platforms. However, the organizations with "inner core" purposes are provided with the annual financial aid of million dollars from several donors and right-wing associations, specially. All these organizations are funded at large scale and led by the people with significant educational backgrounds, for example, by the former head of University of Chicago and Harvard University- Daniel Pipes. Moreover, politicians involved in the Islamophobic wave supports such organizations. For example, Terrorists among Us: Jihad in America was a documentary, produced by Steven Emerson in 1993 on a television. This documentary alleged many American-Muslim foundations to be tied to extremists. Moreover, this work was awarded with two prestigious honors, one was the award of George Polk and the other was the top award from Editors organization and investigative reports for best TV documentary and outstanding investigative report, respectively. Steven Emerson was given the title of "the leading journalistic professional on terrorism of the nation". Traditional outlets of news, mainly Fox News, feature the reports from such networks regularly. CAIR council in 2016 reported the profiles of many such individuals and organizational networks. Specially, the David Yerushalmi's SANE (society of Americans for national existence) involved in Anti-Sharia movements, Brigitte Gabriel's ACT for America, and Pamela Gellar's SIOA (stop islamization of America), involved in the initiation of 2010 anti-ground zero mosque protest and sponsoring the advertisements of buses with anti-Muslim tags in San Francisco and in New York. The center of Southern Poverty Law has published the reports recently stating that the administration of Donald Trump has been appointing the staff tied to the groups against Muslims. Furthermore, CSP (center for security police) and ACT for America have been establishing close and strong linkages with the state and local elected officials.

\section{Islamophobia dissemination}

Among the other bigotry forms, Islamophobia has been spreading through different routes including news channels, TV shows, course books and web-links, campaigns and different political forums. It has been spreading informally, among individuals and generations, just like other bigotries.

\section{News channels}

As Americans are unaware of Muslims personally, so he sole source of information to them about Muslims is the news. This is very challenging as coverage of Muslims by media is mostly negative. According to a mass media analyzing research forum, Media Tenor, around $80 \%$ of the news of Muslims on the channels of CBS and $\mathrm{ABC}$ along with $60 \%$ on the Fox News was all about violence and focused on terrorism, especially between the years 2007-2013. Moreover, in 2018, against the Muslim community $92 \%$ articles were 
published, $78 \%$ against the Jews and $<70 \%$ articles about Africans-Americans, Latinos or Asian-Americans were published. Very few or no reports have been found depicting the ordinary life of the Muslims, be it work life or the student life. Also, no positive contributions of American-Muslims have ever been highlighted. During the era between 2006-2015 Muslims' terrorists attacks were given 3.5 times increased coverage than that of any other community. Likewise, it's been also reported that terrorism suspected Muslims are given 8x additional coverage than that of any non-Muslim, says institute for social policy and understanding. Furthermore, media and law enforcing bodies, both, label the Muslims' violent act as terrorism. Such unjustified reporting reinforces and creates bad and hateful image of Islam and its followers. And Bill Maher, a liberals' commentator and Fox News, the two poles of dogmatic spectrum, presents such negative views. Additionally, if Muslims ever come up with the idea of criticizing the ideology of Muslims as terrorists, then many Americans are given the wrong impression of Muslims' arrogance by news channels. A survey conducted by Pew also stated that $50 \%$ or more of Americans visualize Muslims as biased, as shown by media coverage. Besides these ordinary media channels, hosts of the talk shows and pundits including Michael Savage and Rush Limbaugh, are the outlets that have been bashing the Muslims as a staple topic of their commentary talks since long and fuelling the hatred and terror of Muslims. Washington Times, Rush Limbaugh, National Review, and Savage Nation are some of the regular Islamophobic disseminating outlets of media and the persons behind these broadcasts are considered to be reliable by the general media as they mostly practice scaremongering techniques to ignite the hatred and bigotry against Muslims. Post 2016 elections, Breitbart became very prominent media outlet as it provided platform to many renowned Islamophobes including Frank Gaffney and Pamela Galler under Steve Bannon, the advisor of the former president. However, since 2017, Breitbart has not been considered that much credible and is left with no advertising provision.

\section{Hollywood TV shows as a dissemination platform}

In Hollywood, adverse portrayals of the Arabs (though, not all Muslims are Arab) and Muslims are very common. They have been pictured as desperados, who are backwards, oppressive to women, violent, and terrorists. Jack Sheehan, a media expert, in one of his books has examined numerous films and TV shows portraying Arab characters in orthodox and demeaning ways. He found that Hollywood has been exploiting Arab as a bad guy in their movies and documents. Also, they depict Muslims and Arabs as an enemy of the public, heartless, uncivilized, brutal, and terrorists. Several other authors have also analyzed the Muslims' role as shown on the screens. They says that the representation of the community of Muslims on screens of Television, be it small or big, has principally been driven by anti-blackness, patriarchy, orientalism, imperialism, and anti-Muslim racism. Additionally, an anchor categorized Iranians and Arabs as Subhuman and communally or racially inferior. Over the period of 100 years, this image of Muslims is recreated in antiterrorism actioners featuring doped bombers, rabid hijackers, and bumbling sheikhs etc. Kamran Pasha, a Muslim TV author and director, has described the Hollywood people holding liberal point of views, until or unless it is about Islam and its followers. Also, Kamran recalls the saying of a TV director who said, "Make the villain of story Arab, and not Chinese, as everyone dislikes Arabs". These kinds of realities are enough to explain the seemingly fixture of anti-Arab and anti-Muslim sentiments in the Hollywood, in spite of keen awareness regarding these prevailing adverse representation. Numerous recent TV shows and films broadcasted via major filming studios have illustrated the stereotypic attitude about Muslims and Arabs. Among such shows are 7 Days in Entebbe: showing the rescue of Israeli hostages from the terrorists of Palestine, Beirut, A picture about diplomat of America who is trying to seek a rescue for a colleague who has been caught by the fictitious Islamic release paramilitaries, and The 15:17 to Paris, a show depicting rescue of passengers through Americans from the attack of Muslim hijackers. Furthermore, Aladdin, featuring actors from the background of Middle East, was recreated and been criticized for its stereotypical and orientalist cartoony version. Additionally, Homeland, A TV show was known as the most dogmatic telecast on the screen as it was continuously reconditioning the slanderous and defaming descriptions of Muslims for decades.

\section{Prejudiced literature and web-links:}

\section{Literature}

Post 9/11 war specifically, both fictitious and non-fictitious books were written focusing on the orthodox image of Islam and its followers. For example, Ayaan Hirsi Ali, a former Muslim, wrote many books including, Infidel (2007), Heretic: Why Islam Needs a Reformation Now (2015), The Caged Virgin: An Emancipation 
Proclamation for Women and Islam (2006), and Nomad: From Islam to America: A Personal Journey Through the Clash of Civilizations (2010), and received plentiful recognition, appreciation, and awards for her service. All these books were focused on promoting the Islamophobic mounts that Muslims and their religion is violent, socially inferior or "Other", backward, sexist, and is causing the inter-civilization clashes. Pamela Geller, Robert Spencer, and Bill-Warner are among other famous writers who have written books denouncing or warning about the Muslims and Islam. Warner, a Ph. D mathematician and physicists, and Robert Spencer and Pamela Geller, the notable Islamophobes have written a sequence of books about the description of "political Islam".

\section{Web-links:}

In the network of Islamophobia various web-links have been created by individual beings and groups misrepresenting or demonizing Islam and its followers and tracking "Islamists". Jihad Watch created by Spencer, Islamist Watch directed by Daniel Pipes, and Act! For America managed by Brigitte Gabriel is among the prominent Islamophobia promoting web-pages.

\section{Campaigns against Mosques and Sharia}

\section{Campaigns against Mosque:}

Public campaigns focused on blocking the building and development of the mosques has been among the major emphases of the Islamophobic groups and individuals, which went efficacious sometimes. Among such disreputable campaigns was the one ran in 2010, focused on the projected center of Islamic culture which was decided to be constructed in the lower Manhattan, hardly some blocks away from the place where 9/11 attacks happened. Seldom any opposition were attracted to the project, until Geller, a well-known Islamophobe, presented this project with the point of view that this mosque is a victory mosque which has been built for the celebration of $9 / 11$ attacks, without any evidence. This news kept on circulating in the entire Country with $61 \%$ people found to be opposing this mission. Since then, several flat campaigns have found to be exploding over the construction of planned Mosques including the one in Tennessee and Murfreesboro, whose litigation procedures were dragged for the period of around four years by the opponents. Also, numerous other communities have witnessed like disputes explode, however by the end of the time the mosque was built and operated with no difficulty.

\section{Campaigns against Sharia:}

Countless efforts have been done to target the Muslims and even their faith; some went successful though, to pass the laws against Muslims at the level of state. Many laws were following the template proposed by ALAC (American Laws for American Courts), an organization led by a notable Islamophobe, David Yerushalmi. He is known to be authored a bill against Sharia which adhered to 20 years imprisonment.

\section{Islamophobia and COVID-19}

Combating every niche of racism, inclusive of Islamophobia is a prime concern in an effort to exterminate COVID-19. Discrimination during the pandemic hampers the attempts to cover the causative agent i.e. Virus, and plans a negative portrayal of the Muslims' roles. For example, irrelevant images of the Muslims, which are even not related to the pandemic, including mosques, Muslim ladies with the headscarves on, and Muslim men with beards, supplemented the stories of COVID-19 in the Western world. The major media electronic sources, like CNN, BBC, and The New York Times published the news of suspending the flights from Europe by U.S. and posting the pictures of mosques located in Istanbul to alleviate the coronavirus spread. These kinds of news and publications were the add-ons of the concept that Muslims are behind this pandemic. However, this news was deceptive, because Turkey was not included in the list of the countries that were banned to travel to United States. Mobashra Tazamal, a post-graduate in Islamic studies and societies, and Kristin Garrity Şekerci, a post-graduate in Ethics, peace, and global affairs, says, "These pictures transmit an indirect and subtle message that connects Muslims and their religiousness to terror, around the deadly contagion, infection, and mass sickness". This pandemic has also placed unadorned pre-pandemic Islamophobic structures, like those mounted by the Government of Modi in India. A former deputy editor at the web-link of CFR.org (Council on Foreign Relations) in New York comes up with the argument that the pandemic has aggravated the Muslims demonization in the state, where Islam is blamed for the spread of COVID-19. The worldwide struggle to alleviate the pandemic is also adversely influenced because of 
Islamophobia. A former member of Legislative assembly of Delhi, Sandeep Kumar, and an Indian author, Sumit ray presages that such discernment or discrimination imposes extensive damage through a pandemic because it is the cause of fear in the minority communities and dampens them from disclosing the symptoms. Additionally, this system of non-reporting the symptoms prevents from the progress of "information that is important to catch and fight the deadly harms of rapidly spreading and evolving pandemic". Eeshita Chib, researcher at Indian foreign policy, reports that in United Kingdom's particular case, "Islamophobia is undermining the noteworthy efforts of the community of Muslims to support the national struggle- from functioning at the front...to set up some quality initiatives for the community". As a reaction to the recent violence due to dissemination of Xenophobia, the General-secretary of United States, Antonio Guterres, has urged the states to "devise the strategies for strengthening the protection of their communities counter to the virus of hatred". Nevertheless, anti-pandemic and anti-racism fights are not the parallel efforts. Strategies planned to combat this public health catastrophe are intricately connected to restrict the spread of hatred.

\section{Western Islamophobia in the context of COVID-19}

Law enforcing bodies in the United Kingdom have cautioned that numerous extremist groups are trying to use COVID-19 as a weapon to initiate the attacks against the Muslims. Notably, the extremism activists have been circulating the old pictures and videos of Muslims of Britain praying in the Mosques to portray the Muslims as violating the rules of social distancing over the current countrywide lockdown. The advocate groups of Muslims and the Muslim police have been coming out since then to demystify such claims. Likewise, the hate groups of the United States are continuously disseminating the negative conspiracy speculations, inclusive of the false accusation that the countrywide churches were closed forcefully over the pandemic however mosques stayed open for the religious practices. The president of United States, Donald Trump, also held accused recently of fueling Islamophobia, due to his attitude towards Muslims as compared to that of churchgoers during Ramadan and Easter celebrations respectively. He enforced the strict rules of social distancing on Muslims just to prevent them from praying in the mosques, whereas he was very lenient towards the Christians. Furthermore, media outlets were also found to be contributing towards spreading the hatred against Islam and Muslims. India Today, an Indian media channel for example broadcasted a report in the news with the title of "Madrassas Hotspots" which accused some Islamic schools or madrassas inaccurately of violating the rules of lockdown in the country. Furthermore, an Australian daily news channel, The Österreich OE24, also drew anger against the use of pictures of Muslim ladies wearing hijab in context of suspected pandemic case inclusive of Chinese stewardess.

\section{Strategies of the Muslim world to counter Islamophobia}

COVID-19 has been shown to be particularly noticeable in Islamist militant group persuasion in content of messaging since this alarming outbreak started. IS targeted Ramadan particularly for launching the attacks against Muslims. IS has been looking for exploiting the pandemic-related accusations of susceptible Muslims to disseminate conflicts, recruiting into their ranks, and calling for the attacks. To combat the detrimental dispersion of hateful sentiments related to COVID-19, companies of social network needs to work in collaboration with the health agencies to build protection firewalls against the campaigns of disinformation over- and post-pandemic era. For this purpose false claims and conspiracy theories targeting related to Islamophobia should be removed as they have been tagged as the propaganda of spreading hatred by worldwide health authorities. Moreover, religious thespians can play a significant role by the promotion of solidarity and provision of Islamic guidance, interreligious tolerance and elasticity for the susceptible communities. Additionally, they can guide their audience to recognize myths, rumors, and distortions regarding the religious entities. In this high time of health crisis, institutions of faith are actively positioned for the identification of the vulnerable personas in their societies, and readily provide the much needed support, as and when required. Also, leaders of Islamic world can raise their voice in the global arena against Islamophobia. As, prime minister of Pakistan, Imran Khan, in his current speech to the general assembly of United States, has addressed this issue boldly and vocally. PM Imran Khan said that, "This outbreak was a prospect to unity. Though, unfortunately this pandemic has increased nationalism, fanned the worldwide tensions, and caused the rise in racism and religious enmity, together with the anti-minorities violence in so many places. Also such trends have highlighted 'Islamophobia'. In many states, Muslims are being targeted freely; their shrines are getting destroyed; Holy Messenger (PBUH) being insulted; their divine book- Holy Quran is being burnt- all under the shadow of freedom of expression. A European incident, inclusive of republishing the blasphemous images held by Charlie Hebdo, is among the recent examples. These deliberate 
aggravations and provocations to violence and religion-based hatred need to be outlawed globally. This platform of General Assembly better announce an 'Int'l day to combat Islamophobia' and develop an alliance to battle with this humanity splitting scourge. Every incident provoking Islamophobia is well versed in the directories of UNHCHR, communications from SRHCR, human rights' statements, and organizations of civil societies. Thus the international authority s requested to investigate such grave defilements and prosecute the causative agencies and states involved in these crimes and state terrorism against humanity. SecretaryGeneral is urged to play the lead role in the prevention of these worldwide conflicts. Summit-standard meetings should be convened and hot spots at regional levels should be addressed to resolve these disputes. United Nations is requested to response such challenges of the current era. Inclusively modified UN, together with Security Council is important to endorse democracy, transparency, efficiency, and accountability. Pakistan is all set to contribute in this journey and endeavor, along with the other member countries to develop a conflict-outlawed world with equitable success for everyone with security, harmony, and peace".

\section{FINDINGS AND RECOMMENDATIONS}

Islamophobia is an intricate problem with the major impediments impeding the Muslim world from adopting an operational strategy to fight this prejudice. That's why sequences of applied recommendations are presented, that could be helpful for the member countries and other participants to take necessary steps:

$\checkmark$ Emphasizing the basic human rights and liberties in fighting Islamophobia

$\checkmark$ Implementation of the existing treaties of United Nations on freedom of expression, religious freedoms, and prohibiting the ethnic discrimination, as gears to fight Islamic biasness

$\checkmark$ Encouraging the governments for reviving the alliance of UN configuring civilizations leadership, giving focal attention to divide Muslims and West people which otherwise fuels Islamophobia

$\checkmark$ Adoption of integrated approaches rather than the geographical to eradicate Islamophobia

$\checkmark$ Establishment of strong inter-group connections, who are fighting against religious discrimination, inclusive of anti-Semitism, Christian-phobia, and Islamophobia along with the creation of treaties with several other communities that are subjected to marginalization and dehumanization based on Xenophobia and racial biasness

$\checkmark$ Development of educational centers in the Western world focused on preaching about Islam, similar to those already existing at Harvard universities and Georgetown

$\checkmark$ Internally addressing the factors contributing towards the negative portrayal of Muslims and their religion in the Muslim states and societies, with the emphasis on the significance of Islamic education for youth in order to circumvent the religious ignorance among the current generation

$\checkmark$ Creation of the initiatives for the development of religious and national identity to enhance the contribution of young Muslims to the large scale society in the absence of religious denial

$\checkmark$ Engaging with youth and civilians to implement the programs and actions put forth by the government for addressing religious discrimination

$\checkmark$ Encouraging the subject of inter-religion and inter-faith debates among the member states of OIC to bring about the awareness regarding ethnic interpretations and respective beliefs, and providing an open platform for detailed discussions related to religion and faith

$\checkmark$ Collaboration with the agencies who are working purposefully at the pyramids of societies and grassroots such as Civil Society Organizations (CSOs) and Non-Governmental Organizations (NGOs)

$\checkmark \quad$ Strengthening the preexisting Islamophobia centers by establishing new ones in the member states and in General Secretariat of OIC as well

$\checkmark$ Appointing a special representative for conducting the appointments of OIC with regional, national, and international agencies along with the civil societies

$\checkmark$ Disseminating the Islamophobic reports within the Muslim community, neighboring states, diaspora, widely

$\checkmark$ Highlighting Islamophobia as a global concern to remain as a significant agenda of UNHRC and General Assembly

\section{CONCLUSION}

Islamophobia is provided with the ease worldwide with which wars, occupation, and dictatorship are imposed on the lands where Muslims are living in majority, together with the personal and social discrimination against the Muslim minority states. However, it is not a right choice for Muslim leaders who 
are fighting only against Islamophobia, considering it stand-alone problem - avoiding its backgrounds - a growing wave of bigotry and biasness against every different religion - and denying the consequences - that rebellion doing fear-causing and terrible things to show off attacking Islamophobia. It seems so arrogant to visualize Islamophobia as the main priority or only discrimination in the list of worldwide bigotries. Factually, Islamophobia is among other pathologies, which should be combated altogether. Finally, as it can be seen, the purpose of this research is to highlight the fact that, without legitimate and healthy national organization and scope, having no comprehensive schemes to curtail Islamophobia, numerous sovereign mosques should play bold and definitive role to implement the actions responsible for constructing walls against this Islamophobic culture. Preparing the real-world strategies on all the aforementioned problems, inclusive of training and adjunction of religious leaders, imams, authorities, and all related concerned persons involved in managing the worship inside the mosques, is very compulsory and important. This is how the bulk for mobilization, action, and reflection can be built progressively while attaining the benefits from the opportunities and competencies allowed by the local fields. The nature and gauge of Islamophobia and the way it is connected to the bigotries against rest of the minorities who are diverse, suggests that undoubtedly the tests faced by the "Otherized" minorities of world are seemingly obstinate and exceptional. There exist no ready plans to confront bigotry, though there are numerous examples from which lesson can be taken, including the anti-xenophobic tussle in South Africa purposed for national liberty by the major populations, and civil rights war that occurred in US intended to win socio-economic and political privileges for minorities. Both struggles were focused on citizenship, however. Recognition of citizenship as the heart of every war against Xenophobia or Islamophobia, together with all other bigotry forms; it could prove to be the adhesive holding all the communities which are affected by every manifestation of prejudice. However, it would be crucial enough to do so because bigotry has now dwelled its roots enough to be considered respectable by occupying the conventional discourse and has the capability to become legitimate. Development of strategic or planned leadership is in arena of battle now for equal and inclusive citizenship with pride. Every citizen, even the one who is not suffering biasness directly, can have a capability to remove bigot from supremacy or can obstruct their authority or reverse their influence, for so many reasons, besides their commitment to fail prejudice. The prevalence of all the bigotries, including Islamophobia makes them highly assertive and invincible. However, this pervasiveness could just be the trick convincing the victims of their miseries not to be unique and of the view that they better unite in a planned battle to combat the entire bigotry system.

\section{REFERENCES}

"Statement by the Prime Minister of Pakistan H.E. Imran Khan to the Seventy-fifth Session of the UN General Assembly (25 September 2020)." Ministry of Foreign Affairs. Accessed October 07, 2020. http://mofa.gov.pk/statement-by-the-prime-minister-of-pakistan-h-e-imran-khan-to-the-seventyfifth-session-of-the-un-general-assembly-25-september-2020/\#.

Abbas, Tahir. "Islamophobia as the hidden hand of structural and cultural racism."

Abbas, Tahir. Islamophobia and Radicalisation: A Vicious Cycle. Oxford University Press, 2019.

Abdelkader, Engy. "When Islamophobia turns violent: The 2016 US presidential elections." The Bridge Initiative, Georgetown University (2016).

Aguilera-Carnerero, Carmen, and Abdul Halik Azeez. "Islamonausea, not Islamophobia': The many faces of cyber hate speech." Journal of Arab \& Muslim media research 9, no. 1 (2016): 21-40.

Ali, Saira, and Umi Khattab. "East-west trans-mediatisation of terrorism and Islamophobia: Sydney siege and Peshawar massacre." International Communication Gazette 79, no. 8 (2017): 722-745.

Alkhammash, Reem. "ISLAMOPHOBIA IN THE UK PRINT MEDIA: AN INTERSECTIONAL CRITICAL DISCOURSE ANALYSIS."

Al-Sardia, Ali. "The Manufacture of Islamophobia in America."

Araújo, Marta. "Dominant Islamophobic Narratives-Portugal." CIK: Working Paper 55 (2017).

Ayers, Jessica, Diego Guevara Beltran, Joe Alcock, Cristina Baciu, Scott Claessens, Lee Cronk, Nicole Hudson et al. "How is the COVID-19 pandemic affecting cooperation?." (2020).

Azhari, Naheed. "Islamophobic expressions on Facebook: a critical disclosure analysis on discriminatory discourses following terror attacks in San Bernardino, Brussels and Orlando." Master's thesis, Kuala Lumpur: Kulliyyah of Islamic Revealed Knowledge and Human Sciences, International Islamic University Malaysia, 2019, 2019. 
Barrios Pérez-Coca, Isabel. "Muslims in the UK: the government's role in the rise of Islamophobia." (2018).

Belliappa, Jyothsna Latha, and Srijan Sandip Mandal. "The Value of the Social Sciences in Online Design Education in Light of the COVID-19 Pandemic."

Berntzen, Lars Erik, Reza Zia-Ebrahimi, Magdalena van Ees, and Louie Dean Garcia. "The origins of the concept of Islamophobia."

Bertran, Lurdes Vidal. "Islamophobia, Security Narratives and Countering Violent Extremism: Dangerous Liaisons."

Beshara, Robert K. "A critical discourse analysis of George W. Bush's 'War on Terror'speech: the rhetoric of (counter) terrorism and the logic of Islamophobia." Journal of Language and Discrimination 2, no. 1 (2018): 85-112.

Betz, Hans-Georg. "Populism and islamophobia." In Political Populism, pp. 373-390. Nomos Verlagsgesellschaft mbH \& Co. KG, 2017.

Beydoun, Khaled A. "Islamophobia: Toward a legal definition and framework." Colum. L. Rev. Online 116 (2016): 108.

Beydoun, Khaled A. "Muslim bans and the (re) making of political islamophobia." U. Ill. L. Rev. (2017): 1733.

Beydoun, Khaled A., and Cyra Akila Choudhury. "Islamophobia and the Law: Introduction." Cyra Akila Choudhury \& Khaled A. Beydoun, Islamophobia and the Law (Cambridge University Press 2019), Forthcoming (2019): 19-15.

Bila, Andrea. "Countering Islamophobia in France." In Countering Islamophobia in Europe, pp. 213-251. Palgrave Macmillan, Cham, 2019.

Boyer, Evan. "The Rise of Populism in 21st Century France: Normalizing Islamophobia." (2019).

Brandt, Stefan L. "Fear of an Islamic Planet? Intermedial Exchange and the Rhetoric of Islamophobia." European journal of American studies 15, no. 3 (2020).

Carvalho, Rui. "The need for creative actions in tourism in the Post-COVID 19 pandemic world."

Chehal, Dimple, Parul Gupta, and Payal Gulati. "COVID-19 pandemic lockdown: An emotional health perspective of Indians on Twitter." The International journal of social psychiatry (2020).

Chehal, Dimple, Parul Gupta, and Payal Gulati. COVID-19 pandemic lockdown: An emotional health perspective of Indians on Twitter." International Journal of Social Psychiatry (2020): 0020764020940741.

Cheikh Husain, Sara. "Muslim Community Organizations' Perceptions of Islamophobia: Towards an Informed Countering Response." Religions 11, no. 10 (2020): 485.

Coppola, Marianna, Senatore Immacolata, and Giuseppe Masullo. "Parents in Pandemic: parents' perceptions of risks and psychological, relational, and pedagogical needs in childhood during the COVID-19 emergency in Italy." (2020).

Couto, Naomi. "American Islamophobia: Understanding the Roots and Rise of Fear: by Khaled A. Beydoun, Oakland, University of California Press, 2018, xii+ 245 pp., \$26.95/£ 21.00 (cloth)." (2020): 705-707.

Dorroll, Courtney M., ed. Teaching Islamic Studies in the Age of ISIS, Islamophobia, and the Internet. Indiana University Press, 2019.

Easat-Daas, Amina. Toward a Counter-Islamophobia Toolkit: Drawing on Best Practices in the European Union. The Carter Center, 2018.

Eckert, Stine, Jade Metzger-Riftkin, Sean Kolhoff, and Sydney O'Shay-Wallace. "A hyper differential counterpublic: Muslim social media users and Islamophobia during the 2016 US presidential election." New Media \& Society (2019): 1461444819892283.

El Zahed, Sahar Youssef. "Internalized Islamophobia: The Discursive Construction of "Islam" and "Observant Muslims" in the Egyptian Public Discourse." PhD diss., UCLA, 2019.

Elliott, Heather, and Corinne Squire. "Narratives across media as ways of knowing." In Forum Qualitative Sozialforschung/Forum: Qualitative Social Research, vol. 18, no. 1. 2017.

Enebakk, Vidar. "1001 pieces of Islamist Propaganda?." 1001 Distortions: 265.

Farah Elahi and Omar Khan, ed., "Islamophobia, Still a Challenge for Us All," Runnymede Trust, November 2017, 7. https://www.runnymedetrust.org/uploads/Islamophobia\%20Report\%202018\%20FINAL.pdf

Farhadi, Adib. "The Faces of Islamophobia." In Countering Violent Extremism by Winning Hearts and Minds, pp. 82-112. Springer, Cham, 2020.

Farkas, Johan, and Christina Neumayer. "Mimicking News: How the credibility of an established tabloid is used when disseminating racism." Nordicom Review 41, no. 1 (2020): 1-17. 
Ford, Chandra L. "Commentary: Addressing Inequities in the Era of COVID-19: The Pandemic and the Urgent Need for Critical Race Theory." Family \& Community Health 43, no. 3 (2020): 184-186.

Gada, Mohd Yaseen. "An Analysis of Islamophobia and the Anti-Islam Discourse: Common Themes, Parallel Narratives, and legitimate Apprehensions." The American Journal of Islamic Social Sciences 34, no. 4 (2017): 56-69.

García Nardiz, Rocío. "Islamophobia in France: the position of the Front National on the Charlie Hebdo and November 2015's attacks in Paris." (2019).

George, Cherian. "Hate spin: The twin political strategies of religious incitement and offense-taking." Communication Theory 27, no. 2 (2017): 156-175.

Gorman, Cynthia S., and Karen Culcasi. "Invasion and colonization: Islamophobia and anti-refugee sentiment in West Virginia." Environment and Planning C: Politics and Space (2020): 2399654420943897.

Green, Todd. "Islamophobia." In Oxford Research Encyclopedia of Religion. 2019.

Guimond, Amy Melissa. "Islamophobia and the Talking Heads." In Converting to Islam, pp. 47-68. Palgrave Macmillan, Cham, 2017.

Hafez, Farid. "Muslim Civil Society under Attack: The European Foundation for Democracy's Role in Defaming and Delegitimizing Muslim Civil Society." In Islamophobia and Radicalization, pp. 117-137. Palgrave Macmillan, Cham, 2019.

Hamad, Abdulsalam. "Western Arabo-Islamophobia: Where and When Will It End?." International Journal of Islamic Thought 9 (2016): 1.

Hamdan, Lama. "Framing Islamophobia and Civil Liberties: American Political Discourse Post 9/11." (2019).

Herrchen, Neda Laura, and Marinus RR Ossewaarde. "Pride and Prejudice: The Proliferation of Nationalism and Islamophobia in the context of the European Refugee Crisis." Public Governance Across Borders (2016).

Horsti, Karina. "Digital Islamophobia: The Swedish woman as a figure of pure and dangerous whiteness." New Media \& Society 19, no. 9 (2017): 1440-1457.

Imran, Mashal. "The Immigrant Writes Back: Diasporic Fiction, Gendered Islamophobia, and Living as a Pakistani Muslim Woman in America." PhD diss., Dartmouth College, 2019.

Iner, Derya, and Katy Nebhan. "Islamophobia from within: A case study on Australian Muslim women." In Islamophobia in Muslim majority societies, pp. 199-215. Routledge, 2019.

Iner, Derya. "Interweaving Islamophobia with Radicalism: Feeding the Radicals with the Anti-Halal Debate." In Islamophobia and Radicalization, pp. 73-95. Palgrave Macmillan, Cham, 2019.

Islam, Namira. "Soft Islamophobia." Religions 9, no. 9 (2018): 280.

Islamophobia: Definition of Islamophobia by Oxford Dictionary on Lexico.com also meaning of Islamophobia. (n.d.). Retrieved September 28, 2020, from https://www.lexico.com/definition/islamophobia

Ismail, Hanita Hanim, Arbaayah Ali Termizi, and Radzuwan Ab Rashid. "De-'Moor'Tifying Shakespeare's Othello: Iago as a Renaissance Form of Islamophobia." International Journal of English Linguistics 8, no. 7 (2018).

Jackson, Leonie B. Islamophobia in Britain: The making of a Muslim enemy. Springer, 2017.

Jehan-Robert, Aude. "The rise of Islamophobia in Western Europe and the EU counter violent extremism policy responses."

Kevern, Peter, Ruth Gelehrter da Costa Lopes, Áurea Eleutério Barroso, Beltrina Côrte, and Carolina Lucena. "The Contribution of Church-Based Networks to Social Care in the Coronavirus Pandemic and Beyond: The Case of Pastoral da Pessoa Idosa in Brazil." Religions 11, no. 10 (2020): 486.

Khaled, Alaa Ali. "MUSLIM WOMEN NETWORKS: ISLAMIC KNOWLEDGE [RE] PRODUCTION AND THE PREMISES OF EMPOWERMENT THROUGH TRANSMISSION AND DISSEMINATION." PhD diss., 2020.

Kołodko, Grzegorz W. "After the Calamity: Economics and Politics in the Post-Pandemic World." Polish Sociological Review 210, no. 2 (2020): 137-156.

Krishnan, Kavita. "Covid-19 in India:'Relief work has been left to the people'." Green Left Weekly 1262 (2020): 1.

Laverick, Wendy, and Peter Joyce. "Islamophobia and the Social Cohesion Agenda." In Racial and Religious Hate Crime, pp. 177-246. Palgrave Macmillan, Cham, 2019.

Law, Ian, Amina Easat-Daas, and S. Sayyid. "Counter-Islamophobia Kit: Briefing Paper and Toolkit of CounterNarratives to Islamophobia." (2018).

Lee, Pamela M. "Face Time, Pandemic Style." October (2020): 230-241. 
McQueen, Fraser. "France's 'elites', Islamophobia, and communities of friendship in Sabri Louatah's Les Sauvages." Modern \& Contemporary France 26, no. 1 (2018): 77-90.

Mescoli, Elsa. "Countering Islamophobia in Belgium." In Countering Islamophobia in Europe, pp. 253-287. Palgrave Macmillan, Cham, 2019.

Mohamad, Mohamad Zaidin, S. H. S. Omar, Muhamad Zaid Ismail, Sofyuddin Yusof, and Azli Fairuz Laki. "The Dissemination of Dakwah through the Instrument of Civilizational Dialogue and Wasatiyyah according to Nursi's Thought." International Journal of Academic Research in Business and Social Sciences 7, no. 10 (2017): 341-346.

Najib, Kawtar, and Peter Hopkins. "Where does Islamophobia take place and who is involved? Reflections from Paris and London." Social \& Cultural Geography 21, no. 4 (2020): 458-478.

Opratko, Benjamin. "Islamophobia: The bigger picture." Historical Materialism 25, no. 1 (2017): 63-89.

Padovan, Dario, and Alfredo Alietti. "PREDICTING RACISM: ASociological PATTERN OF ANTI-SEMITISM AND ISLAMOPHOBIA."

Pavan, Annalisa. "Information and Dialogue in the Struggle against Islamophobia: The Jeddah Declaration for a Culture of Moderation." World 4, no. 2 (2017).

Pearson, Elizabeth, and Emily Winterbotham. "Women, gender and daesh radicalisation: A milieu approach." The RUSI Journal 162, no. 3 (2017): 60-72.

Perocco, Fabio. "Anti-migrant Islamophobia in Europe. Social roots, mechanisms and actors." REMHU: Revista Interdisciplinar da Mobilidade Humana 26, no. 53 (2018): 25-40.

Peucker, Mario. "Islamophobia and Stigmatising Discourses: A Driving Force for Muslim Active Citizenship?." In Islamophobia and Radicalization, pp. 245-264. Palgrave Macmillan, Cham, 2019.

Qureshi, Sajda. "Outrage and anger in a global pandemic: flipping the script on healthcare." (2020): 445-457.

Reed, Haley Haley Patricia. "Framing of immigrants and refugees: A content analysis of mainstream and partisan news coverage of immigration." PhD diss., University of Missouri--Columbia, 2017.

Renton, James, and Ben Gidley, eds. Antisemitism and Islamophobia in Europe: a shared story?. Springer, 2017.

Risman, Barbara J. "An Issue of Feminist Analysis: During a Global Pandemic." (2020): 545-546.

Rodríguez Maeso, Silvia. "Dominant Counter-Narratives to Islamophobia-Portugal." CIK: Working Paper 1515 (2018).

Roose, Joshua M., and Bryan S. Turner. "Islamophobia, Science and the Advocacy Concept." Society 56, no. 3 (2019): 210-221.

Rouse, Carolyn M. "It's all free speech until someone dies in a pandemic." Anthropology Now 12, no. 1 (2020): 66-72.

Rowe, E. (2020). Reading Islamophobia in education policy through a lens of critical race theory: a study of the 'funding freeze'for private Islamic schools in Australia. Whiteness and Education, 5(1), 54-73.

Runnymede Trust, Commission on British Muslims and Islamophobia, Islamophobia: A Challenge for Us All, https://www.runnymedetrust.org/uploads/publications/pdfs/islamophobia.pdf

Safdari, N. "The Sensationalization of the" Homophobic Muslim": Tracing the Roots of Islamophobia and Homophobia." (2019).

Schiller, Nina Glick. "Solidarities of the Dispossessed: Response to Julia Eckert in the Time of Pandemic."

Short, Sarah. "Religious Jurisprudence and Islamophobia, The United States, France, and Canada." (2018).

Stam, Valerie Monique. "'It is not possible to be Dutch, and Muslim, and Black:" Second-Generation Youths' Everyday Practices of Resisting Racism and Islamophobia in the Netherlands." PhD diss., Carleton University, 2019.

Sunar, Lütfi. "The long history of Islam as a collective "other" of the west and the rise of Islamophobia in the US after Trump." Insight Turkey 19, no. 3 (2017): 35-52.

The Runnymede Trust is a race equality think tank founded in 1968 by Jim Rose and Anthony Lester, with the aim of promoting a multi-ethnic Britain. In 1996, the Runnymede Trust established the Commission on British Muslims and Islamophobia, chaired by Gordon Conway, the vice-chancellor of the

Tsimouris, Giorgos. "Islamophobia and radicalisation: a vicious cycle: by Tahir Abbas, London, C. Hurst \& Co, 2019, XXVIII+ 246 pp., 53.34\$(hardcover), ISBN: 9781787382015." (2020): 1-3.

University of Sussex: https://www.runnymedetrust.org/about.html

Ushama, Thameem. "ISLAMOPHOBIA IN INDIA: AN EXPLORATION OF ITS ROOTS, RISE AND HISTORY." AlShajarah: Journal of the International Institute of Islamic Thought and Civilization (ISTAC) 25, no. 1 (2020): 1-29. 
Vidgen, Bertram. "Tweeting Islamophobia." PhD diss., University of Oxford, 2019.

Vidra, Zsuzsanna. "Counter-Islamophobia Kit: Dominant Islamophobic Narratives-Hungary." (2017).

Vieten, Ulrike M. "The "New Normal" and "Pandemic Populism": The COVID-19 Crisis and Anti-Hygienic Mobilisation of the Far-Right." Social Sciences 9, no. 9 (2020): 165.

Watt, Diane Patricia. "Muslim female students confront Islamophobia: Negotiating identities in-between family, schooling, and the mass media." Journal of Family Diversity in Education 2, no. 1 (2016): 21-36.

Webb, Helena, Marina Jirotka, Bernd Carsten Stahl, William Housley, Adam Edwards, Matthew Williams, Rob Procter, Omer Rana, and Pete Burnap. "The ethical challenges of publishing Twitter data for research dissemination." In Proceedings of the 2017 ACM on Web Science Conference, pp. 339-348. 2017.

Yassine, Lobna, and Linda Briskman. "Islamophobia and social work collusion." Working Across Difference 55 (2019): 53-68.

Yilmaz, Ihsan. "Religio-Secular Counter-Hegemonic Legal Knowledge Production and Its Glocal Dissemination." Available at SSRN 3485400 (2019).

Yusuf, Imtiyaz. "Three Faces of the Rohingya Crisis: Religious Nationalism, Asian Islamophobia, and Delegitimizing Citizenship." Studia Islamika 25, no. 3 (2018): 503-542.

Zempi, Irene, and Imran Awan. Islamophobia: lived experiences of online and offline victimisation. Policy Press, 2016.

Zeweri, Helena. "Beyond Response and Representation: Muslim Australian Women Reimagining AntiIslamophobia Politics." Feminist Formations 32, no. 2 (2020): 111-135. 